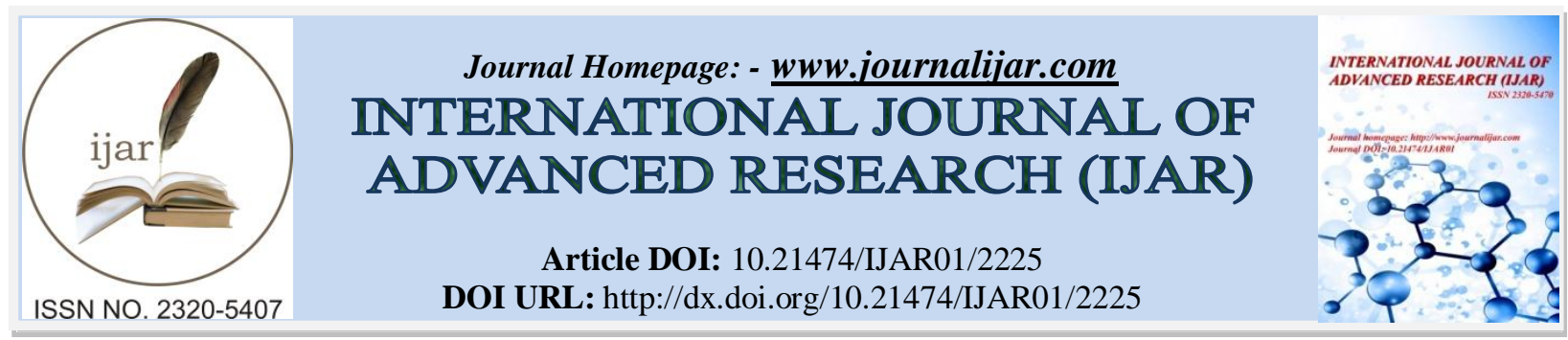

RESEARCH ARTICLE

\title{
DETECTION OF PHYTOCHEMICALS IN COW URINE AND THEIR ROLE AS ANTIMUTAGENS.
}

Farida P. Minocheherhomji.

Department of Microbiology, B. P. Baria Science Institute, Navsari - 396445, Gujarat, India.

\section{Manuscript Info}

Manuscript History

Received: 28 September 2016

Final Accepted: 30 October 2016

Published: November 2016

Key words:-

Anticarcinogenic agent, Antimutagenic activity, Cow urine, Phytochemical constituents.

\begin{abstract}
Cow urine is used for various ailments by Ayurvedic and Unani pharmacy and also by traditional healers. This study was aimed at carrying out phytochemical analysis and antimutagenic activity of Cow urine. Phytochemical screening revealed the presence of alkaloids, carbohydrates, protiens, steroids, terpenoids and cardioglycosides. Phenolic flavonoids, phlobatannins, anthrocyanins, anthraquinone, tannins and saponoins were totally absent. Cow urine is an important source of substances claimed to induce antimutagenic effect. Cow urine works as an antimutagenic agent due to the antioxidant property of uric acid and allantoin present in it. Cow urine has been granted U.S. patents (No. 6, 896, 907 and 6, 410,059) for its medicinal properties and it functioning as an anticarcinogenic agent. Cow urine has been observed to increase the potency of "Taxol" (paclitaxel) against MCF7, a human breast cancer cell-line in invitro assays (U.S. patent No. 6, $410,059)$. Ames test is used for the study of the antimutagenic effect of cow urine when used in combination against sodium azide, 2nitrofluorine and mitomycin $\mathrm{C}$ in absence of metabolic inhibitor (Sq). Combinations of varying concentrations were checked and the percentage of inhibition was determined using the formula: [(a-b)/(ac)]x100. The combination showed a gradual respective decrease in the number of revertant colonies against tester strains Salmonella typhimurium TA 100, TA 1535, TA 98 and TA 102. The percentage inhibition ranged from $5 \%$ to $85 \%$.

Copy Right, IJAR, 2016,. All rights reserved.
\end{abstract}

\section{Introduction:-}

Indian Ayurvedic doctors regularly use cow urine as a natural medicine to treat many common disorders ${ }^{1}$. Very few attempts have been made to correlate scientifically the nature of cow urine. In order to correlate ancient and traditional knowledge of use of cow urine with the scientific methodologies and parameters of modern times, this study has been done using cow urine in different forms as immunomodulatory and antioxidant agent ${ }^{4,6}$.

In Sushrita Samhita, cow urine has been described as an extremely effective substance or material secretion of animal origin having a wide and innumerable therapeutic value. In India, oral consumption of cow urine has been prescribed and practiced since ages. Effect of cow urine along with a combination of medicinal plants, has been found to enhance its effectiveness in the cure of diabetes, cancer, and $\operatorname{AIDS}^{12}$. This type of an alternative and combo treatment is referred to as "Cowpathy".

Corresponding Author:- Farida P. Minocheherhomji.

Address:- Department of Microbiology, B. P. Baria Science Institute, Navsari - 396445, Gujarat, India. 
Traditional medicines have recommended direct consumption of cow urine as an effective medicine which is easily available and very easily affordable. It contains twenty four types of salts, phenol, potash, iron, calcium, phosphorus and lactose. Phenol, being the major material constituent of cow urine exhibits antiseptic activity. It is a mixture of phenol and cresol.

Cow urine has also been observed to lead to the increase in potency of "Taxol" (pactitaxel) against MCF -7, a human breast cancer cell line "invitro assays" (U.S. Patent Numbers 6, 059, 410). These significant achievements highlights the potential role of cow urine in the treatment of various bacterial infections and also cancer, thus proving that cow urine plays a prominent role in enhancing the efficacy and potency of other drugs.

The objective of the present study is to make a deep search into the bio enhancing property and the impact of the naturally available products, so that they can be used to combat many common diseases. Bio enhancing is one of the many properties of cow urine. It promotes and increases the effectiveness of antimicrobial, antifungal, and anticarcinogenic drugs. It also leads to an increase in the activity of gonadotropin releasing hormone conjugate with bovine serum albumin and zinc $^{3}$.

Phytochemical analysis of cow urine has also shown the presence of tannins and phlobatannins, which are responsible for antimutagenic activity 9 . Today, bacteria are being used for the assessment of antimutagenic activities of these different compounds in a short time with excellent results. One of the methods used for assessing the mutation prevention properties of a compound in bacteria is the Ames test ${ }^{\mathbf{4 , 5}}$.

Ames test is a worldwide short term bacterial reverse mutation test. It is known so because new mutation at the site of the pre existing mutation can restore the gene function and allow the cells to synthesize Histidine. The test is designed for screening a variety of new chemical substances and drugs that can produce genetic damage that leads to gene mutation $^{\mathbf{8}, \mathbf{1 1}}$. The Salmonella typhimurium strains used in the test have different mutations in various genes in the Histidine operon, and each of these mutations are designed to be responsive to mutagenic agents via different mechanisms ${ }^{11,13}$.

\section{Materials and Methods:- Procurement of Cow Urine:-}

Fresh cow urine has been procured from pure Indian breed Junagadh Gir cow based at the Goshala of Gurukulsupa near Navsari for use in this study. Fresh urine collected was filtered and centrifuged in order to remove all the debris and precipitated materials. Cow urine is then sterilized by autoclaving it at $121{ }^{\circ} \mathrm{C}$ and $15 \mathrm{lb} / \mathrm{sq}$ inch pressure for 20 minutes. It is then preserved at $4{ }^{\circ} \mathrm{C}$ for further long time use ${ }^{\mathbf{1 2}}$. In order to assure that the cow urine is free of microbes, it is inoculated in broth and also on nutrient agar plate, and sterility is tested.

\section{Phytochemical Screening:-}

Sterile cow urine was subjected to standard procedures for carrying out different qualitative chemical tests in order to recognize the constituents $2,7,14,15,16$.

Procedure Adopted for Qualitative Analysis of the Phytochemical Constituents:-

\begin{tabular}{|c|c|}
\hline Alkaloids & $\begin{array}{l}1 \mathrm{ml} \text { of the filtrate on mixing with } 2 \mathrm{ml} \text { of Dragenddroff's reagent shows a development of } \\
\text { turbid orange colour. }\end{array}$ \\
\hline Tannins & $\begin{array}{l}1 \mathrm{ml} \text { of the filtrate on mixing with } 2 \mathrm{ml} \text { of Ferric chloride promotes a development of dark } \\
\text { green colour. }\end{array}$ \\
\hline Saponins & $\begin{array}{l}1 \mathrm{ml} \text { of the filtrate is added to } 2 \mathrm{ml} \text { of distilled water and shaken vigorously. It is then allowed } \\
\text { to stand for } 10 \text { minutes. Foam formation on the top layer of the mixture, which remains for } 9 \text { to } \\
11 \text { minutes is an indication of the presence of saponins. }\end{array}$ \\
\hline Anthraquinones & $\begin{array}{l}1 \mathrm{ml} \text { of the filtrate is mixed with } 10 \mathrm{ml} \text { of benzene, and is then filtered. } 5 \mathrm{ml} \text { of } 10 \% \text { ammonia } \\
(\mathrm{v} / \mathrm{v}) \text { is then added to the above filtrate and shaken vigorously. Development of pink tone in the } \\
\text { solution points the presence of anthraquinones. }\end{array}$ \\
\hline Anthrocyanides & $1 \mathrm{ml}$ of the filtrate when mixed with $5 \mathrm{ml}$ of dilute $\mathrm{HCl}$ gives pale pink tone. \\
\hline $\begin{array}{l}\text { Phenolic } \\
\text { flavonoids }\end{array}$ & $\begin{array}{l}1 \mathrm{ml} \text { of the filtrate when mixed with } 2 \mathrm{ml} \text { of } 10 \% \text { lead acetate leads to the formation of brown } \\
\text { precipitates. }\end{array}$ \\
\hline Flavonoids & $\begin{array}{l}1 \mathrm{ml} \text { of the filtrate on mixing with } 2 \mathrm{ml} \text { of dilute sodium hydroxide shows the development of } \\
\text { golden yellow tone. }\end{array}$ \\
\hline
\end{tabular}




\begin{tabular}{|c|c|}
\hline Carbohydrates & $\begin{array}{l}\text { 1. } 1 \mathrm{ml} \text { of the filtrate is mixed together with } 5 \mathrm{ml} \text { of Benedict's reagent and boiled for } 5-6 \\
\text { minutes. Formation a bluish green colour, which shows the presence of carbohydrates. } \\
\text { 2. Addition of a } 2-3 \text { drops of Molisch's reagent and } 2-3 \text { drops of concentrated } \mathrm{H}_{2} \mathrm{SO}_{4} \text { to } 1 \mathrm{ml} \\
\text { of the filtrate, gives a purple colour. } \\
\text { 3. Addition of few drops of Fehling's A reagent to } 1 \mathrm{ml} \text { of the filtrate, leads to the } \\
\text { development of green colour. } \\
\text { 4. Addition of few drops of Fehling's B reagent to } 1 \mathrm{ml} \text { of the filtrate, leads to the } \\
\text { development of brown colour }\end{array}$ \\
\hline Proteins & $\begin{array}{l}\text { Addition of } 5 \text { to } 6 \text { drops of Million's reagent to } 1 \mathrm{ml} \text { of the filtrate, leads to the formation of } \\
\text { white precipitates, turning red on heating. }\end{array}$ \\
\hline Steroids & $\begin{array}{l}1 \mathrm{ml} \text { of chloroform and } 1 \mathrm{ml} \text { of } \mathrm{H}_{2} \mathrm{SO}_{4} \text { are added slowly by the sides of the test tube containing } \\
1 \mathrm{ml} \text { of the filtrate. If the upper layer turns red in tone and the sulphuric acid layer exhibits a } \\
\text { greenish yellow fluorescence, then steroids are present. }\end{array}$ \\
\hline Terpenoids & $\begin{array}{l}\text { Addition of } 2 \mathrm{ml} \text { chloroform and a } 2-3 \text { drops of concentrated sulphuric acid carefully to } 1 \mathrm{ml} \text { of } \\
\text { the filtrate leads to the development of reddish brown colour at the interface. }\end{array}$ \\
\hline $\begin{array}{l}\text { Cardiac } \\
\text { Glycosides }\end{array}$ & $\begin{array}{l}\text { Addition of } 1 \mathrm{ml} \text { of } \mathrm{FeCl}_{3} \text { reagent (consisting of } 1 \text { volume of } 5 \% \mathrm{FeCl}_{3} \text { solution and } 99 \text { volume } \\
\text { of Glacial acetic acid) and a few drops of concentrated sulphuric acid, greenish blue colour } \\
\text { appears within few minutes. }\end{array}$ \\
\hline Phlobatannins & $\begin{array}{l}\text { Addition of few drops of } 1 \% \mathrm{HCl} \text { to } 1 \mathrm{ml} \text { of the filtrate leads to the formation of red } \\
\text { precipitates. }\end{array}$ \\
\hline
\end{tabular}

List of Tester Strains and Positive Controls as Mutagenic Agents:-

\begin{tabular}{|c|c|c|}
\hline TA100 & Sodium azide & $\mu \mathrm{g} /$ Plate \\
\hline TA98 & 2-Nitrofluorine & $\mu \mathrm{g} /$ Plate \\
\hline TA102 & Mitomycin C & $\mu \mathrm{g} /$ Plate \\
\hline TA1535 & Sodium azide & $0.5 \mu \mathrm{g} /$ Plate \\
\hline TA1537 & 9- Aminoacridine hydrochloride hydrate & $75.0 \mu \mathrm{g} /$ Plate \\
\hline
\end{tabular}

Anti Mutagenecity Test:-

1. Two tubes, each containing $2 \mathrm{ml}$ of top agar with histidine and biotin $(0.5 \mathrm{mM})$, previously melted and maintained at $45 \pm 2{ }^{\circ} \mathrm{C}$ was used for plating.

2. A volume of $0.5 \mathrm{ml}$ of $0.2 \mathrm{M}$ phosphate buffer was added to each tube in the absence of $\mathrm{S} 9$ mix.

3. In one set, $100 \mu \mathrm{L}$ of different concentrations of mixture of cow urine and plant extract were added to the above mixture.

4. In the second set, $100 \mu \mathrm{L}$ of different concentrations of cow urine and relevant mutagen for each strain were added to the above serial no. 1 and 2 mixtures. The concentrations of the test sample for investigating the antimutagenicity were: 25,50 and $100 \mu \mathrm{L} /$ Plate. These were tested against sodium azide (5.0 $\mu \mathrm{g} /$ Plate) in TA 100 and TA 1535; 2-Nitrofluorine (7.5 $\mu \mathrm{g}$ / Plate) in TA 98; Mitocymin C (0.5 $\mu \mathrm{g} /$ Plate) in TA 102; and, 9-Aminoacridine Hydrochloride Hydrate (75.0 $\mu \mathrm{g}$ / Plate) in TA 1537.

5. For the negative control, $100 \mu \mathrm{L}$ of sterile distilled water was added.

6. For the positive control, $100 \mu \mathrm{L}$ of relevant mutagen were added for each tester strain.

7. Finally, $100 \mu \mathrm{L}$ of overnight grown standard bacterial culture were added to all the top agar tubes.

8. The mixture was added to all the top agar tubes.

9. All the tubes were kept in a water bath maintained at $37^{\circ} \mathrm{C}$ for 30 minutes.

10. The contents were mixed thoroughly and rapidly transferred to the individual petri dishes containing Minimal Glucose Agar.

11. After solidification of the contents, the petri dishes were inverted and incubated at $37 \pm 1^{\circ} \mathrm{C}$ for $48-72$ hours and then assessed by scoring the number of revertant colonies of individual plates ${ }^{5,10}$.

Results and Discussion:-

Table 01:- Phytochemical Analysis of Cow Urine Sample.

\begin{tabular}{|l|c|c|}
\hline Detection test for & \multicolumn{2}{|l|}{ Cow Urine Sample } \\
\hline & Present $\bullet$ & Absent $\circ$ \\
\hline Alkaloids: Dragendorff's Test & $\bullet$ & \\
\hline Tannins & & 0 \\
\hline
\end{tabular}




\begin{tabular}{|c|c|c|}
\hline Saponins & & 0 \\
\hline Anthraquinone & & O \\
\hline Anthrocyanosid & & $\mathrm{O}$ \\
\hline Phenolic flavonoids & $\bullet$ & \\
\hline Flavonoids & & o \\
\hline Carbohydrates: Benedicts test & $\bullet$ & \\
\hline Proteins & $\bullet$ & \\
\hline Steroids & $\bullet$ & \\
\hline Terpenoids & $\bullet$ & \\
\hline Cardiac glycosides & $\bullet$ & \\
\hline Phlobatannins & & O \\
\hline
\end{tabular}

Table 01 shows the phytochemical analysis of cow urine to indicate the presence of alkaloids, phenolic flavanoids, steroids, terpenoids, cardiacglycosides, carbohydrates and proteins. They are all responsible for antimicrobial activity invitro and invivo.

\section{Anti Mutagenecity Test:-}

Cow urine was tested for their antimutagenic activity against sodium azide, 2-nitrofluorine, 9-aminoacridine hydrochloride hydrate and mitomycin C induced mutagenicity in the tester stains TA100 and TA1535, TA98, TA1537 and TA102 respectively. Varying effects on cow urine on the direct acting mutagen s induced mutagenicity in one or more tester strains are presented in the Table 02. The inhibitory activity was expressed as percentage decrease of reverse mutation.

$\%$ inhibition $=[(a-b) /(a-c)] \times 100$

Where,

a » Number of histidine revertants induced by mutagen

b » Number of histidine revertants induced by mutagen in the presence of cow urine

c » Number of revertant induced in negative control

Table 02:- Number of Revertant Colonies.

\begin{tabular}{|c|c|c|c|c|c|c|c|c|c|c|}
\hline \multirow{3}{*}{ Concentrations $(\mu \mathrm{l} / \mathrm{plate})$} & \multicolumn{10}{|c|}{$\begin{array}{l}\text { His }^{+} \text {Revertant Colonies/Plate } \\
\text { (Absence of Metabolic Activation) }\end{array}$} \\
\hline & \multicolumn{2}{|c|}{ TA1537 } & \multicolumn{2}{|c|}{ TA1535 } & \multicolumn{2}{|c|}{ TA98 } & \multicolumn{2}{|c|}{ TA100 } & \multicolumn{2}{|c|}{ TA102 } \\
\hline & R1 & R2 & R1 & $\mathbf{R 2}$ & R1 & $\mathbf{R 2}$ & R1 & R2 & R1 & R2 \\
\hline $\mathrm{NC}$ & 1 & 4 & 16 & 13 & 21 & 21 & 120 & 132 & 215 & 229 \\
\hline $\mathrm{NC}+\mathrm{CU}$ & 2 & 4 & 14 & 13 & 18 & 19 & 132 & 128 & 191 & 212 \\
\hline PC & 287 & 263 & 160 & 170 & 485 & 425 & 670 & 685 & 985 & 1112 \\
\hline $\mathrm{PC}+\mathrm{HD}$ & 280 & 243 & 75 & 68 & 197 & 208 & 101 & 97 & 208 & 316 \\
\hline $\mathrm{PC}+\mathrm{MD}$ & 276 & 232 & 110 & 90 & 260 & 255 & 160 & 156 & 301 & 418 \\
\hline $\mathbf{P C}+\mathbf{L D}$ & 279 & 240 & 112 & 102 & 390 & 395 & 420 & 417 & 984 & 990 \\
\hline
\end{tabular}

Notations in Table 02:-

\begin{tabular}{|l|l|}
\hline $\mathbf{N C}$ & Sterile Distilled Water, $100 \mu \mathrm{L} /$ Plate \\
\hline $\mathbf{N C}+\mathbf{C U}$ & Sterile Distilled Water, $100 \mu \mathrm{L} /$ Plate + Cow Urine, $100 \mu \mathrm{L} /$ Plate \\
\hline PC & For TA1537: 9- Aminoacridine hydrochloride hydrate, $75.0 \mu \mathrm{g} /$ Plate, \\
& For TA1535: Sodium Azide, $0.5 \mu \mathrm{g} /$ Plate \\
& $\begin{array}{l}\text { For TA98: 2-Nitrofluorine, } 7.5 \mu \mathrm{g} / \text { Plate } \\
\text { For TA100: Sodium Azide, } 5.0 \mu \mathrm{g} / \text { Plate } \\
\text { For TA102: Mitomycin C, } 0.5 \mu \mathrm{g} / \text { Plate }\end{array}$ \\
\hline HD & $100 \mu \mathrm{L}$ Cow Urine / Plate \\
\hline MD & $50 \mu \mathrm{L}$ Cow Urine / Plate \\
\hline LD & $25 \mu \mathrm{L}$ Cow Urine / Plate \\
\hline
\end{tabular}


Table 03:- Percentage Reduction in Number of Revertant Colonies.

\begin{tabular}{|l|l|l|l|l|l|}
\hline \multirow{2}{*}{$\begin{array}{l}\text { Concentration } \\
\boldsymbol{\mu} \text { / Plate }\end{array}$} & \multicolumn{5}{|c|}{$\begin{array}{l}\text { His }{ }^{+} \text {Revertant Colonies/Plate } \\
\text { (Absence of Metabolic Activation) }\end{array}$} \\
\cline { 2 - 6 } & TA1537 & TA1535 & TA98 & TA100 & TA102 \\
\hline PC & 0.0 & 0.0 & 0.00 & 0.0 & 0.00 \\
\hline HD & 5.0 & 56.55 & 55.2 & 85.35 & 75.25 \\
\hline MD & 7.8 & 39.1 & 43.2 & 76.65 & 65.9 \\
\hline LD & 5.75 & 35.0 & 13.3 & 38.2 & 5.55 \\
\hline
\end{tabular}

Notations in Table 03:-

\begin{tabular}{|l|l|}
\hline PC & For TA1537: 9- Aminoacridine hydrochloride hydrate, $75.0 \mu \mathrm{g} /$ Plate \\
& $\begin{array}{l}\text { For TA1535: Sodium azide, } 0.5 \mu \mathrm{g} / \text { Plate } \\
\text { For TA98: 2-Nitrofluorine, } 7.5 \mu \mathrm{g} / \text { Plate } \\
\text { For TA100: Sodium azide, } 5.0 \mu \mathrm{g} / \text { Plate } \\
\text { For TA102: Mitomycin C, } 0.5 \mu \mathrm{g} / \text { Plate }\end{array}$ \\
\hline HD & $100 \mu \mathrm{L}$ Cow Urine / Plate \\
\hline MD & $50 \mu \mathrm{L}$ Cow Urine / Plate \\
\hline LD & $25 \mu \mathrm{L}$ Cow Urine / Plate \\
\hline
\end{tabular}

\section{Conclusion:-}

- Cow urine exhibited nearly 50\% decrease in the number of revertants colonies against sodium azide, 2nitrofluorine and mitomycin $\mathrm{C}$ induced mutagenicity in the tester stains TA98, and TA1535 whereas there was more than 75\% decrease in tester strain TA100 and TA102 at high concentration of cow urine of $100 \mu \mathrm{L} /$ Plate.

- At $50 \mu \mathrm{L} /$ Plate concentration of cow urine, percent inhibition of mutagenicity against sodium azide, 2nitrofluorine and mitomycin $\mathrm{C}$ ranged from $7.8 \%$ to $76.65 \%$. (Table.2) Tester strain TA102 and TA100 the percentage decrease was from $65 \%$ to $77 \%$. whereas the rest of the strains showed moderate results.

- At $25 \mu \mathrm{L} /$ Plate concentration of cow urine, percentage inhibition of mutagenicity against sodium azide, 2nitrofluorine and mitomycin $\mathrm{C}$ was unremarkable. Hence, it can be concluded that Antimutagenic activity of the cow urine is concentration dependent.

- The presence of phytochemicals like alkaloids, phenolic flavanoids, steroids, terpenoids, cardiacglycosides, carbohydrates and proteins are accounted to be responsible for their antimutagenic nature.

\section{Bibliography:-}

1. Chopra RN, Chopra IC (2006); Indigenous Drugs of India.

2. Edeoga HO, Okwu DE, Mbabie BO (2005); Phytochemical constituents of some Nigerian medicinal plants; African Journal of Biotechnology, 4: 685-688.

3. Ganaie Javid A, Shrivastava Vinoy K (2010); Effects of gonadotropin releasing hormone conjugate immunization and bioenhancing role of kamdhenu ark on estrous cycle, serum estradiol and progesterone levels in female Mus musculus; Iranian Journal of Reproductive Medicine; 8(2): 70-75.

4. Ganguly S, Prasad A (2010); Role of plant extracts and cow urine distillate as immunomodulator in comparision to Levamisole - A review; Journal of Immunology and Immunopathology, 12(2): 91-94.

5. Ghazali AR, Abdullah R, Ramli N, Rajab NF, Ahmad-Kamal MS, Yahya NA (2011); Mutagenic and antimutagenic activities of mitrayna speciosa korth extract using Ames test; Journal of Medicinal Plants Research, 5(8): 1345-1348.

6. Gosavi DD, Sachdev D, Salwe K (2011); Immunomodulatory and antioxidant effect of gomutra ark in rats; Journal of Mahatma Gandhi Institute of Medical Sciences, 16(ii): 37-41.

7. Harbone JB (1998); Phytochemical Methods $3^{\text {rd }}$ edition; Chapman and Hall, London, ISBN: 0-412-57260-5, 1302.

8. Imanishi H, Sasaki YF, Ohta T, Watanabe M, Kato T, Shirasu Y (1991); Tea tannin components modify the induction of sister chromatid exchanges and chromosome aberrations in mutagen treated cultured mammalian cells and mice; Mutation Research, 259: 79-88.

9. Kada T, Kaneko K, Matsuzaki S, Matsuzaki T, Hara Y (1985); Detection and chemical identification of natural bio antigens; Mutation Research, US National Library of Medicine, National Institutes of Health, 150(1-2): 127-132.

10. Maron DR, Ames BN (1983); Revised methods for the Salmonella mutagenecity test; Mutation Research, 113: 173-215. 
11. Mortelmans K, Zeiger E (2000); The Ames salmonella/microsome mutagenecity assay; Mutation Research, 455: 29-60.

12. Randhwa GK (2010); Cow urine distillate as bio enhancer; Journal of Ayurveda and Integrate Medicine, 1(4): 240-241.

13. Shams A, Mehrabian S, Irian S (2012); Assessing the antioxidant and anticarcinogenic activities of virgin olive oil and purified olive oil samples treated with light and heat using the Ames test; International Journal of Microbiology Research, 4: 173-177.

14. Sofowora A, Oguyemi AO (1993); Proceedings of a conference on African medicinal plants, Ife-Ife; Univ, Life; 1979: 20-22.

15. Tanaka K, Hayatsu T, Negishi T, Hayatsu H (1998); Inhibition of N-nitrosation of secondary amines in vitro by tea extracts and catechins; Mutation Research, 412: 91-98.

16. Trease and Evans (2007); PHARMACOGNOSY, $15^{\text {th }}$ Edition W.B. Saunders. 